\title{
Alkalmazott matematikai feladatok egy középiskolásoknak tartott foglalkozáson
}

\section{Applied Mathematics Exercises in a Secondary Grammar School Lesson}

\author{
CS. KÉZI \\ Debreceni Egyetem, Mûsszaki Kar, Műszaki Alaptárgyi Tanszék, kezicsaba@science.unideb.hu
}

Absztrakt. Az EFOP-3.6.1-16-2016-00022 azonosítószámú „Debrecen Venture Catapult Program" pályázat támogatásával 2019. májusában középiskolások számára három tanórás foglalkozást tartottam Mátészalkán, az Esze Tamás Gimnáziumban. Ezen a foglalkozáson a tanulók számára több olyan feladatot prezentáltam, amely a matematika különböző területeken való alkalmazásait mutatja.

Abstract. In the frame of the project EFOP-3.6.1-16-2016-00022 „Debrecen Venture Catapult Program" on may, 2019, I maked a test and it was completed by a secondary grammar school students in Mátészalka. In this lesson there were many exercises that showcase the different applications of mathematics.

\section{Bevezetés}

Az EFOP-3.6.1-16-2016-00022 projekt keretében 2019. májusban három tanórás foglalkozást tartottam a mátészalkai Esze Tamás Gimnáziumban. Ezen a foglalkozáson egyrészt alkalmazott matematikai feladatokat mutattam be a tanulóknak, másrészt egy tesztet töltettem ki velük annak felmérésére, hogy milyen típusú feladatokkal foglalkoznak szívesebben, alkalmazott matematikai vagy klasszikus „tisztán” matematikai feladatokkal.

Két, azonos létszámú osztályban írattam meg a dolgozatot. Az osztályok mindegyikében ugyanaz a középiskolai tanár tanította a matematikát és az előzetes mérések alapján a két osztály azonos képességű tanulókból áll.

A tesztet kitöltők 12. osztályosak voltak. Az egyik osztályban „klasszikus matematikai” szövegezésű feladatok szerepeltek a tesztben, a másik osztályban ugyanazok a feladatok alkalmazásszemléletű megfogalmazásban szerepeltek. 


\section{A foglalkozáson bemutatott feladatok}

1. feladat: Összeöntünk 200 gramm $30 \frac{\mathrm{m}}{\mathrm{m}} \%$-os ecetsav oldatot és 150 gramm $15 \frac{\mathrm{m}}{\mathrm{m}} \%$-os ecetsav oldatot. Mennyi lesz a kapott oldat koncentrációja?

2. feladat: Hány gramm vizet kell elpárologtatni $15\left[\frac{\mathrm{m}}{\mathrm{m}} \%\right]$-os és $1,5\left[\frac{\mathrm{g}}{\mathrm{cm}^{3}}\right]$ sűrúségű oldat $1\left[\mathrm{~cm}^{3}\right]$-éből, hogy a készítendő oldat $30\left[\frac{m}{m} \%\right]$-os legyen?

3. feladat: Egy részecske hely-idő függvénye: $s(t)=t^{2}-4 t, t \in[0 ; 4]$, ahol az időt másodpercben, a megtett uatat méterben mérjük. Adjuk meg a sebesség-idő függvényt és a gyorsulás-idő függvényt!

A fizika órán a tanulók kísérletet végeztek és tömegmérés volt a feladat. Tizenöt tanuló végzett méréseket és az alábbi eredményeket kapták gramm pontossággal:

$15 ; 14 ; 14 ; 15 ; 13 ; 13 ; 14 ; 14 ; 15 ; 16 ; 15 ; 14 ; 15 ; 14 ; 13$.

Adjuk meg a minta átlagát egész grammra kerekítve! Határozzuk meg a mediánt, a móduszt és a terjedelmet! Számoljuk ki a szórásnégyzetet!

4. feladat: A $P$ anyagi pont erő hatására az

$$
k:(x-2)^{2}+(y+4)^{2}=25
$$

egyenletű körön mozog. Amikor a $Q(-1 ; 0)$ pontba érkezik az erő hatása megszűnik. Írjuk fel a további pályájának egyenletét! Áthalad-e az anyagi pont a $(-5 ;-3)$ ponton.

5. feladat: Egy változtatható nyílású, szabályos hatszög alakú csavaranya oldala $a=2[\mathrm{~cm}]$ hosszúságú. Milyen $x$ nyílást kell választanunk ahhoz, hogy a csavaranya és a csavarkulcs között pontosan 0,6 [mm] hézag legyen?

6. feladat: Egy változtatható nyílású, szabályos hatszög alakú csavaranya oldala $a=2[\mathrm{~cm}]$ hosszúságú. Milyen $x$ nyílást kell választanunk ahhoz, hogy a csavaranya és a csavarkulcs között pontosan 0,6 [ $\mathrm{mm}]$ hézag legyen?

7. feladat: Egy 15 [N]-os és egy 60 [N]-os erő hat egy pontszerű testre. Az erők által bezárt szög $30^{0}$. Határozzuk meg az eredő erő nagyságát!

8. feladat: Egy kikötőből egyszerre indul el két hajó. Az egyik $40\left[\frac{\mathrm{km}}{\mathrm{h}}\right]$, a másik $30\left[\frac{\mathrm{km}}{\mathrm{h}}\right]$ sebességgel halad. Az első hajó észak felé, a másik kelet-délkeleti irányban halad. Milyen messze lesznek egymástól 5 óra múlva?

9. feladat: Egy antenna magasságának meghatározásához a síkságon egy egyenesen felveszük egy egyenesen rendre az $A, B$ és $C$ pontokat úgy, hogy $A B=40$ méter és $B C=20$ méter. A felvett pontokból az antenna rendre $30^{\circ}, 45^{\circ}, 60^{\circ}$ szög alatt látszik. Milyen magas az antenna?

10. feladat: Mennyi ecetsavból és nátrium-acetátból tudunk $10 \mathrm{~cm}^{3}$ térfogatú, 5,0 pH-értékű puffert készíteni? 
11. feladat: Milyen vastag egy 1,5 gramm tömegű szatniollap, amely $30 \mathrm{~cm}$ hosszú és $15 \mathrm{~cm}$ széles. A sûrüség $7\left[\frac{\mathrm{g}}{\mathrm{cm}^{3}}\right]$.

12. feladat: Mekkora a kapilláris cső belső átmérője, ha 100 mg higany 6 mm magasságig töltötte meg a csövet. A higany sürűsége $13,6\left[\frac{\mathrm{g}}{\mathrm{cm}^{3}}\right]$.

13. feladat: Hány hl víz van egy kútban, amely 2 méter széles és a víz 3 méter magasan áll benne?

14. feladat: Egy szivattyú dugattyújának átmérője $16 \mathrm{~cm}$. A lökethossz $40 \mathrm{~cm}$. Percenként 100-szor szív és nyom. Hatásfoka 0,85. Mennyi vizet szállít percenként a szivattyú?

15. feladat: Egy 50 méter hosszú rézdrót tömege $5 \mathrm{~kg}$. Mekkora az átmérője. A réz sűrüsége $8,8\left[\frac{\mathrm{kg}}{\mathrm{dm}^{3}}\right]$.

16. feladat: Egy 12 centiméter magas gyertya 6 óra alatt ég el. Feltételezzük, hogy az égésük az idő függvényében egyenletesen következik be, azaz a gyertya égését elsőfokú függvénnyel modellezzük. Ábrázoljuk a gyertya magasságát az idő függvényében!

17. feladat: Egyenletesen gyorsuló gépkocsi álló helyzetből indulva $100\left[\frac{\mathrm{km}}{\mathrm{h}}\right]$ sebességet ér el. Mekkora utat tesz meg ezen idő alatt? Ábrázoljuk a mozgás hely-idő függvényét!

18. feladat: A koordinátarendszer kezdőpontjából induló lövedék röppályáját az

$$
f(x)=x-0,1 x^{2}
$$

függvény írja le. Mekkora a lövedék által elért legnagyobb magasság?

19. feladat: A h hosszúságú fonálinga lengési ideje:

$$
t=2 \pi \cdot \sqrt{h \cdot g^{-1}}
$$

ahol $g$ gravitációs gyorsulás értéke. Fejezzük ki a képletből a $h$ mennyiséget! Számoljuk ki a $h$ pontos értékét, ha $g=9,81\left[\frac{m}{s^{2}}\right]$ és $t=20[\mathrm{~s}]$. Adjuk meg a választ két tizedesjegyre kerekítve is! Adjunk szöveges választ!

20. feladat: A tej tömegének 8\% -a tejszín. A tejszín tömegének 60\% -a vaj. Hány kg tejből készíthető $5 \mathrm{~kg}$ vaj?

21. feladat: Egy 15000 forintos farmer árát 20\%-kal felemelik, majd az emelt árat 20\%-kal csökkentik. Mennyibe kerül most a farmer? Hány \%-os volt az árváltozás?

22. feladat: Az álló helyzetből egyenletes gyorsulással induló vonat $20 \mathrm{~s}$ alatt $200 \mathrm{~m}$ utat tesz meg. Ábrázoljuk a menetidőt a megtett út függvényében!

23. feladat: Egy szupermarket egy bizonyos típusú DVD-lejátszóból egy év alatt 4500 darabot értékesít 600 \$ áron. Amennyiben az árat 10 \$-ral csökkentik, úgy az eladott mennyiség 200 darabbal növekszik. Az eladott mennyiség és az eladási ár között elsőfokú függvénykapcsolatot feltételezünk! Határozzuk meg a keresleti függvényt! Adjuk meg azt az árat, amelyhez tartozó kereslet 0 darab!

24. feladat: Egy város lakóinak számát a 


$$
P(t)=20000 \cdot 2^{0,012 t}
$$

függvénnyel modellezzük, ahol P(0) a város lakóinak száma 2 010-ben. Hányan laktak a városban 2 010ben? Hányan laktak a városban 2 018-ban? A modell szerint hány lakosa lesz a városnak 2050-re?

25. feladat: Egy domb tetején álló kilátó magasságát keressük. A kilátó aljától induló lejtős úton lefelé haladva 20 métert, a kilátó $45^{\circ}$-os szögben látszik. További 50 métert haladva a kilátó 20 alatt látszik. Milyen magas a torony?

A foglalkozás megtartása után két osztályban két különböző tesztet töltettem ki. Mindkét osztályban ugyanaz a középiskolai tanár tanította a matematikát. Az egyik osztályban tisztán matematikai szemléletű feladatokat kaptak a tanulók, a másik osztályban az ezeknek megfelelő alkalmazott matematikai feladatokat.

\section{Matematikai megfogalmazású tesztkérdések}

1. feladat: Egy számtani sorozat első tagja 10, differenciája 2.

a) Adjuk meg a sorozat 10. tagját!

b) Határozzuk meg azt a legkisebb „,n” egész számot, amelyre az első „,n” tag összege legalább 623.

2. feladat: Egy egyenes körhenger magassága 80 [cm], alapkörének sugara 50 [cm]. Számoljuk ki a felszínét és térfogatát!

3. feladat: Tekintsük az $f(x)=1000+15 x$ függvényt!

a) Számoljuk ki az $f(60)$ értéket, azaz adjuk meg a függvény helyettesítési értékét az $x=60$ helyen!

b) Adjuk meg azt az „x” valós számot, amelyre $f(x)=3000$.

c) Vázoljuk fel az „f" függvény grafikonját!

4. feladat: Oldjuk meg a $0,88 x+\frac{4}{5} x-x=714$ egyenletet a valós számok halmazán!

\section{Alkalmazásszemléletű tesztfeladatok}

1. feladat: A Harry Potter és a Félvér Herceg című könyv 623 oldalas. Első nap 10 oldalt olvasunk belőle. Mivel nagy rajongói vagyunk a könyvnek és a történet egyre izgalmasabb, ezért elhatározzuk, hogy minden nap 2 oldallal többet olvasunk, mint az előző napon.

a) Ha tartjuk magunkat ahhoz, amit terveztünk, akkor hány oldalt fogunk olvasni a 10. napon?

b) Hány nap alatt olvassuk el a könyvet?

c) Hány oldalt fogunk olvasni az utolsó nap?

2. feladat: Henger alakú, felül nyitott tartályt kívülről lefestenek. A tartály magassága 80 [cm], alapkörének sugara 50 [cm]. Egy négyzetméter lefestéséhez 4 [dkg] festéket használnak fel. Mennyi festéket kell venni, ha kétszer kell a tartályt lefesteni? 
3. feladat: Telefonszámlánk úgy áll elő, hogy 1000 forintos havi alapdíjat fizetünk, ezen kívül percenként 15 forintot minden telefonbeszélgetés esetén.

a) Ha egy hónapban 1 órát telefonálunk, mennyi lesz a telefonszámlánk?

b) Ha a 3000 forintot nem léphetjük túl egy hónapban, akkor hány percet telefonálhatunk maximum?

c) Ábrázoljuk a fizetendő összeget a lebeszélt percek számának függvényében!

4. feladat: Anna és Zsuzsi is szeretné megvenni az újságosnál az egyik magazint, de egyik lánynak sincs elegendő pénze. Anna pénzéből hiányzik a magazin árának 12\%-a, Zsuzsi pénzéből pedig az ár egyötöde. Ezért elhatározzák, hogy közösen veszik meg a magazint. A vásárlás után összesen 714 Ft-juk maradt.

a) Mennyibe került a magazin?

b) Mennyi pénzük volt a lányoknak külön-külön a vásárlás előtt?

\section{Az egyes feladatcsoportokra adott helyes válaszok számának összehasonlítása}

Mindkét osztályban 30-30 fő írta meg a tesztet. Az alábbi diagram mutatja az egyes feladatokra a helyes válaszok számát:

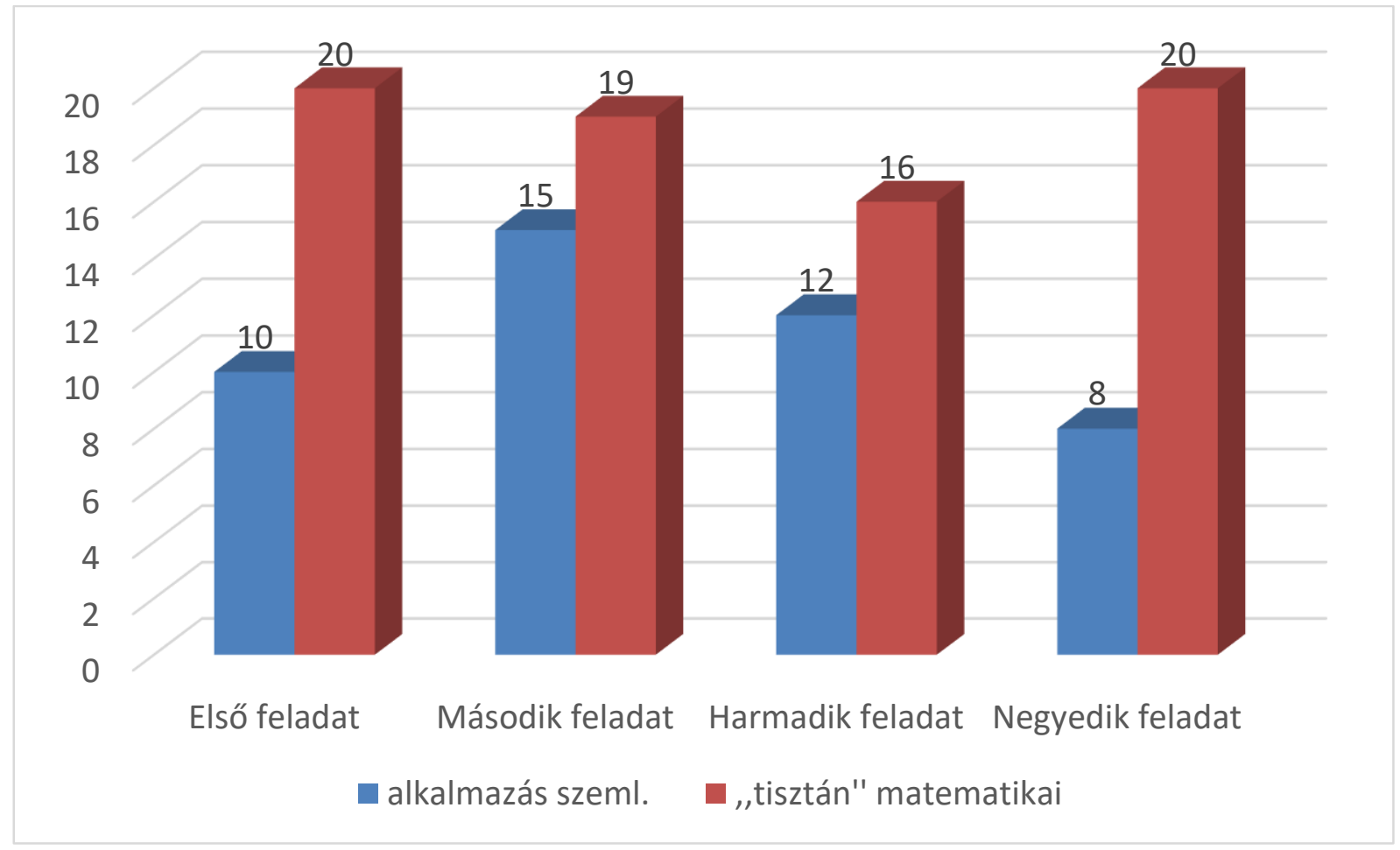

1.ábra: helyes válaszok száma

Azt láthatjuk, hogy minden egyes feladatnál a „tisztán matematikai” feladatokat nagyobb arányban oldják meg helyesen, mint az alkalmazásszemléletű feladatokat. 
Azt vehetjük észre, hogy a tanulók tudnak ugyan gondolkodni, azonban a lexikális tudások meglehetősen hiányos matematikából.

Ezen eredmény véleményem szerint részben annak is köszönhető, hogy a diákok középiskolában nagyban támoszkodnak a függvénytáblázat használatára, így nem rendelkeznek a feladatok megoldásához szükséges alapösszefüggések ismeretével.

Összegezve az eredményeket azt tapasztaljuk, hogy a tanulók szívesen foglalkoznak a „tiszta” matematikai feladatok helyett inkább alkalmazásszemléletű feladatokkal, azonban a modellalkotási készségük meglehetősen hiányos. Sok esetben nem tudják értelmezni a szöveget vagy nem tűnik fel számukra, ha olyan eredményt kapnak, ami nem értelmezhető. Például kaptak olyan megoldást, hogy negatív szám jött ki a napok számára, de nem tűnt fel számukra, hogy ez vagy hibás megoldás miatt származhat, vagy azon okból, hogy esetleg nincs megoldása a feladatnak.

Annak ellenére, hogy nagyobb motivációt éreznek az alkalmazásorientált feladatok megoldására, ezeket mégis nehezebben, több hibával oldják meg.

A modellalkotási készség fejlesztésére érdemes minél több alkalmazásszemléletű feladatot megoldaniuk. Ezek iránt a lelkesedésük is nagyobb és a formális gondolkodásuk is fejleszthető.

\section{Hivatkozások}

[1] Horváth Á, Logikai feladatok középiskolásoknak, ELTE szakdolgozat, 2012.

[2] Szanyi Gy, Kézi Cs, Matematika alap-, közép- és emelt szinten (Készüljünk a felvételire a „mindennapok” matematikájával), Debreceni Egyetem, 2018.

[3] www.oktatas.hu

\section{Köszönetnyilvánítás}

A cikk elkészülését az EFOP-3.6.1-16-2016-00022 azonosítószámú projekt támogatta. 